\title{
腰下肢痛に対する硬膜外ブック療法 および低周波置鍼療法の効果
}

熊本県 木原外科医院 ペインクリニック 日本良導絡自律神経学会常任理事

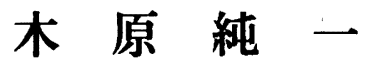

腰下肢痛を主訴としてペインクリニック外来 を受診する患者は、年間 500 600例で新患数の 中で常に上位を占めている。

我々は、これらの腰下肢痛の保存的療法とし て効果の高い神経ブロック療法や、これと比べ ると劇的な効果は少ないものの手軽で副作用や 合併症の殆んどない低周波置鐡療法や、良緮絡 治療を施行している。

神経ブロック療法では、まず硬膜外ブロック を行い、これにて効果の余り期待できないとき は、椎間関節ブロックや神経根ブロックなどを 症例に応じて施行している。検査の必要な症例 は、例えば仙骨部硬膜外造影、選択的神経根造 影などのように神経ブロックも同時に施行し、 検查も治療の一部として行っている。

今回我々は初診時より低周波通電のみ行った 症例群と、これに神経ブロック療法を併用した 症例群の治療効果について比較検討したので報 告する。

\section{[対象]}

対象となった症例は、腰下肢痛を主訴とし、 ペインクリニック外来を受診した患者589例で ある。その内低周波置鋮療法のみ施行した 152 例（A群）と低周波置錯療法に神経ブロック療 法を併用した437例（B群）に分けて検索を行っ た。

症例の内訳は $\mathrm{A}$ 群男性82例、女性70例で、平 均年齢は $48.9 \pm 10.5$ 歳（ $8 \sim 84$ 歳）であった。 B群は男性215例、女性 222 例で平均年齢は 46.2 歳 (16〜82歳)であった。

対象疾患は、椎間板ヘルニア、変形性脊椎症、
脊柱管狭窄症、脊椎分離之り症、椎間関節症、 骨粗箖症、腰部筋々膜症、その他である。各群 の疾患別分類を図 1 に示した。（図 1)

それぞれ平均年齢、症例数、男女別症例数を 示している。

低周波置鐵療法のみ施行した症例は、疼痛が 比較的軽度なものや、激しい痛みがあり神経ブ ロック療法を薦めたが、患者の希望で低周波置 鍼療法のみ施行した症例である。

\section{〔治痖方法〕}

低周波置鐵療法は、腰下肢の圧痛点と放散痛 などの方向によって病側の大腸脈、委中、崑崙 などの経穴、良導点に電極刺入穴を選択した。 原則として 1 回につき 4 力所を穿刺刺激頻度 2 〜30HZの交流波で 1 回につき18分間の通電を 1〜2 日間隔で行った。治療回数は $5 \sim 10$ 回を 要した。さらに症例によっては良導絡治療を加 えた。(図G)

神経ブロック療法は、腰部硬膜外ブロックを 主体とし 1 ～ 2 日間隔で施行。局麻剂は $0.5 \%$ リドカイン $5 \sim 8 \mathrm{~m} \ell$ を体格、年龄に応じて適宜 使用した。治療回数はVisual Analog Scale （V.A.S）ペインスコアが3以下になるまで を原則とし、平均 $3 \sim 5$ 回を必要とした。これ にて効果の期待できない場合には、仙骨部硬膜 外ブロック、椎間関節ブロック、神経根ブロッ クなどを症例に応じて適宜加えた。

(図H.I.J.K)

\section{【治㙩効果判定〕}

治療終了 3 力月後に電話又は来院してもらい、 図 2 に示す治療効果判定基準により効果判定を 
行った。(図 2)

\section{【結果]}

各疾患群と全症例の治療成績は図 3、4 に示 すとおりである。

前症例のうち著効例はA群38\%、B群 (43\%)、 有効例は $\mathrm{A}$ 群 $10 \%$ 、B群 $(29 \%)$ 、不变例 $\mathrm{A}$ 群 $22 \% 、 B$ 群 (19\%) であり、A群、B群に有意 差を認めなかった。

しかしながら各疾患別にみるとA群では、変 形性脊椎症、骨粗箖症、腰部筋々膜症が、B群 では椎間板ヘルニア、脊柱管狭窄症、椎間関節 症が著効、有効例が、やや多い傾向を示した。

個々の症例をみると、急性の強度の疼痛を伴 う腰部筋々膜症、椎間関節症などの症例に対し ては、良導絡治療や神経ブロック療法が奏効し た。慢性の難治性疼痛や、覀急性腰痛、愁訴の 多い腰痛に対して低周波置銊療法は、神経ブロッ ク療法と変わらない、時には優れた鎮痛効果を 示した。

疼痛が激しく、疼痛性跛行を呈するような腰 部椎間板ヘルニアや脊柱管狭窄症に対しては、 低周波置銊療法、良導絡治療法の除痛効果は余 り期待できなかった。結果的には腰部硬膜外ブ ロック（局麻+ステロイド注入）(16例）や神 経根ブロック（5 例）を併用した。

これにて改善がみられず、手術を要した症例 は 8 例、椎間板ヘルニア 7 例、脊柱管狭窄症 1 例であった。

\section{[考察]}

良導治療法は、直流電気を使用するため強刺 激となり、速効的で急性の強い疼痛に有効であ り、低周波置鍼療法は中等度の痛覚刺激を特定 の部位で行うため、慢性の難治性疼痛に効果的 である。大阪医大の兵頭らは、発症 6 力月以内 の急性抢よび覀急性腰痛症例に対して、低周波 置銊療法は、硬膜外ブロックや神経根ブロック などの神経ブロック療法に劣らない鎮痛効果を 有すると報告している。

我々の症例でも同様な傾向にあった。

しかしながら、強い疼痛性跛行を訴える脊柱管 狭窄症や根症状を呈する椎間板ヘルニアの症例 には無効であった。

良導絡治療法、低周波置鐵療法の作用機序に
ついては、局所血流量の増加、内因性オピオイ ド物質の放出、疼痛伝導路抑制するゲートコン トロール説、下行性抑制系などにより説明され ているが、まだ不明な点が多い。

\section{（図M.P.N.O）}

神経ブロック療法の作用機序についても同様 であるが、第一に考えられるのは交感神経ブロッ クにより痛みの悪循環を断っていることであり （図Q）、これが、神経ブロック併用群の成績が、 疾患によっては多少なりとも勝っていた理由で あろう。

\section{〔結語〕}

1. ペインクリニックに於ける腰下肢痛に対す る低周波置鐵療法と神経ブロック併用療法の治 療効果を比較検討した。

2. 各疾患群により多少の差はあるが、両群に 有意差はなかった。

3. 急性の強度の疼痛を伴う腰部筋々膜症、椎 間関節症などに対しては、良導絡治療が奏効し た。

4. 慢性の難治性疼痛や亜急性腰痛に対して低 周波置鍼療法は神経ブロックと変わらない鎮痛 効果を有している。

5. 疼痛が激しく疼痛性跛行を呈するような腰 部椎間板ヘルニアや脊柱管狭窄症などに対して は、低周波置鍼療法、良導絡治療法の除痛効果 は余り期待できない。

6. 良導絡治療、低周波置鍼療法が奏効しない 症例に体しては、神経ブロック療法を併用する ことが望ましい。

7. 神経ブロック療法の効果も得られない場合 は、腰痛の原因の再検索と入院治療、さらには 整形外科的手術療法の検討も考慮に入れるべき である。

8. ペインクリニック外来においては、神経ブ ロック療法のみならず、良導絡治療法、低周波 置鍼療法は少ない侵襲で、神経ブロック療法に 勝とも劣らない鎮痛作用を有することから、腰 下肢痛の患者にファストチョイスとして、まず 施行されるべき有効な治療法であると考えられ る。 


\section{考支文献}

1) Todd AJ, Mckenzie J : GABA-immunoreactive neurons in the dorsal horn of the spinal cord. Neurosci 32 : 799 806, 1989.

2) Wang KM, Yao SM, Xian YL, et al:A study of the receptive field of acupoints and the relationship between characteristics of needling sensation and groups of afferent fibres. Sci Sin $28: 963 \sim 971$, 1985.

3 ) Rees H, Roberts MHT: Antinociceptive effects of dorsal column stimulation in the rat : Involvement of anterior pretectal nucleus. J. Physiol 417 : 375 388, 1989.

4 ) Boasher D: Termination of the central pain pathway in man : the conscious appreciation of pain, Brain $80: 606 \sim 622$, 1957.

5 ) Mayer DJ, Liebeskind JC : Pain reduction by focal electrical stimulation of the brain : An Anatomical and behavioral analysis. Brain Res 68 : 79, 1974.

6 ) Kuru M : Sensory paths in the spinal cord and brain stem of man. Tokyo Sogensaya, 1949.

7) Kumazawa T, Perl ER : Exzcitation of marginal and substantia gelatinosa neurons in the primate spinal cord : indications of their place in dorsal horn functional organization. J Comp Neurol 177417 434, 1978.

8 ) Hosobuchi Y, Adams JE, Linchitz R : Pain relief by electrical stimulation of central gray matter in humans and its reversal by naloxone. Science 197: 183 〜 186, 1977.

9 ) Kenetter GA, Haber LH, Yezierski RP, et al : Cells of origin of the spinoreticular tract in the monkey. $\mathrm{J}$ Comp Neurol $207: 61 \sim 74,1982$.

10) Duggan AW, Foong FW : Bicuculline and spinal inhibitation produced by dorsal column stimulation in the cat. Pain 22 :
249 259, 1985.

11) Bowsher $D:$ Role of the reticular formation in response to noxious stimulation. Pain 2 : 361 378, 1976.

12) Beitz AJ : The sites of origin of brainstem neurotensin and serotonin projections to the rodent nucleus raphe magnus. J Neurosci 2 : 829 834, 1982.

13) Kirwan EO'G : Back pain-Textbook of pain. New York, churchill Livingstone, 1989,335 340.

14) Li Qun, Lu Shunde, Luo Jimin, et al : An observation on the therapeutic effect of acupuncture in the treatment of sciatica. J Trad chinese Med 9 : 90 92, 1989.

15) Borenstein DG, Wiesel SW : Low back pain.Philadelphia WB Saunders, 1989, 491 $\sim 493$.

16) Anonymous : How does acupuncture wark? Br Med J 283 : 746 748, 1981.

17）恩地裕、上野良三 : 整形外科ペインクリニッ ク : 184 236, 1986

18） David Bowsher、兵頭正義訳 : 刺激鎮痛法 の生理学: ペインクリニック. 12. NO 4 . 485〜492. 1991

19）若杉文吉、大瀬戸清茂 : 腰下肢痛の神経ブ ロック療法. ペインクリニック $7: 281$ 290,1986

20）兵頭正義 : 腰痛に対する硬膜外ブロック療 法および針众療法. ペインクリニック : 291 〜301, 1986

21）若杉文吉 : 神経ブロック療法. ペインクリ ニック $7: 141 \sim 149,1986$

22）若杉文吉 : ペインクリニック. 神経ブロッ ク法. $68 \sim 80,1988$

23）若杉文吉 : 腰下肢痛の神経ブロック療法. 日本ペインクリニック学会総会号 : $15 \sim 17$, 1985

24）大瀬戸清茂、若杉文吉 : 腰下肢痛 Medical Way $2: 90 \sim 96,1985$

25）兵頭正義：腰痛に対する硬膜外ブロック療 法. ペインクリニック $3: 357 \sim 364,1982$

26）道上松巨、他：腰部椎間板ヘルニア術後疼 
痛患者の治療成績、ペインクリニック 4：

$149 \sim 156,1983$

27）福田精一、兵頭正義 : 腰部椎間板ヘルニア に対する腰部硬膜外ブロック療法。ペイン クリニック $4: 255 \sim 261,1983$

\section{図 1 疾患別分類}

\begin{tabular}{|c|c|c|c|c|}
\hline 窉 名 & 平均年部 & 应 数 & 男 & 女 \\
\hline 䊒䦌板へルニア & 43. $2(43.1)$ & $62(182)$ & $38(110)$ & $24(72)$ \\
\hline 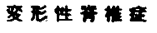 & $66.5(65.7)$ & $35(108)$ & $18(62)$ & $17(46)$ \\
\hline 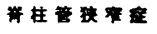 & $67.2(66.7)$ & $18(42)$ & $10(27)$ & $8(15)$ \\
\hline 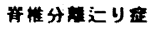 & $53(52)$ & $7(11)$ & $5(10)$ & $2(1)$ \\
\hline 䊒用的笛垔 & $42(43)$ & $5(6)$ & $3(4)$ & $2(2)$ \\
\hline 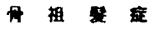 & $75.4(74.6)$ & $5(7)$ & $0(1)$ & $5(6)$ \\
\hline 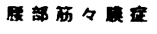 & $40.5(41.2)$ & $12(21)$ & $10(16)$ & $2(5)$ \\
\hline z & $50.2(48.9)$ & $8(60)$ & $6(40)$ & $2(20)$ \\
\hline 企 酽 & $51.1(17.8)$ & $152(437)$ & $90(270)$ & $62(167)$ \\
\hline
\end{tabular}

\section{図 1 等踈周辺の模断図}
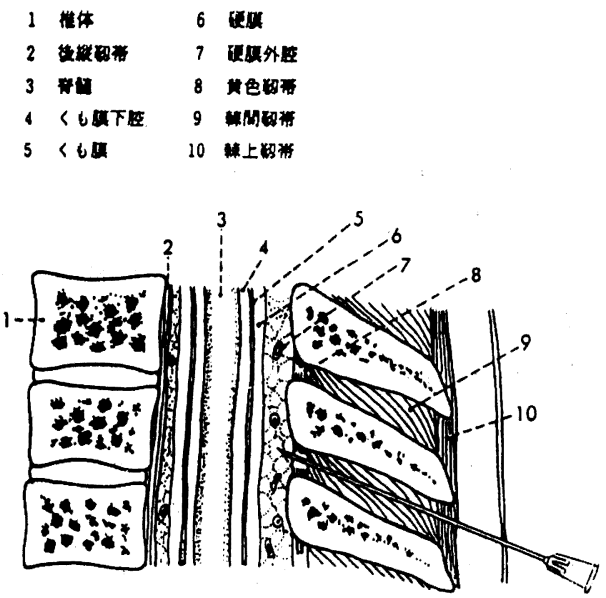

28）兵頭正義：ペインクリニックにおけるハリ 療法の効用. 臨床と研究53:75～80, 1976

29）小川節郎：痛みにおける交感神経の関与. ペインクリニック $3: 317 〜 322,1986$

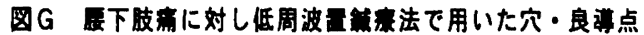

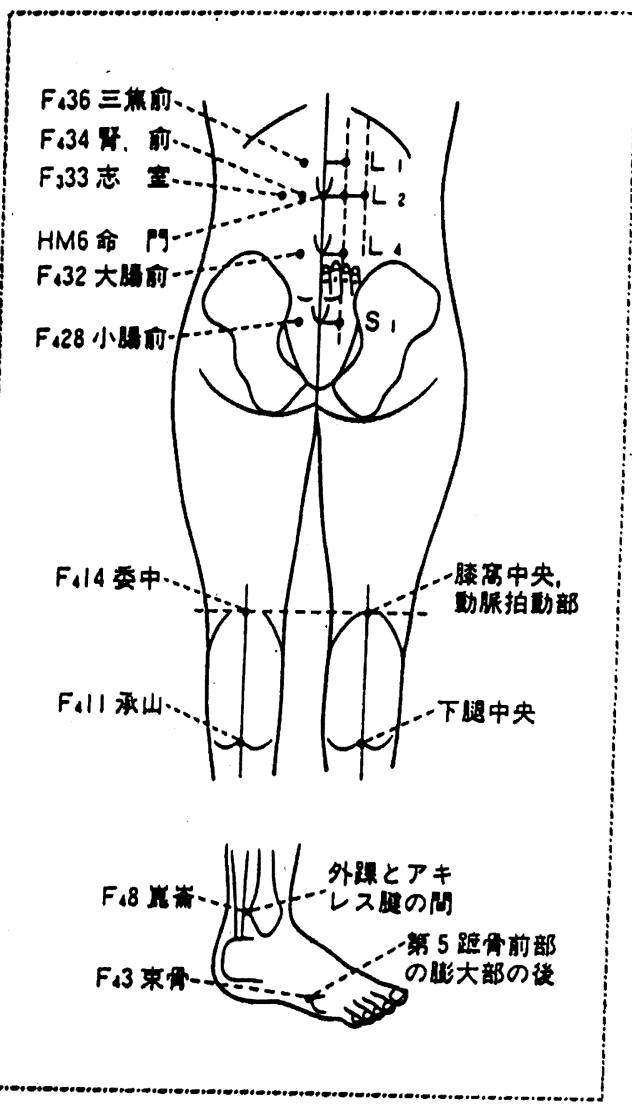

図H 脊能周辺の絴断図
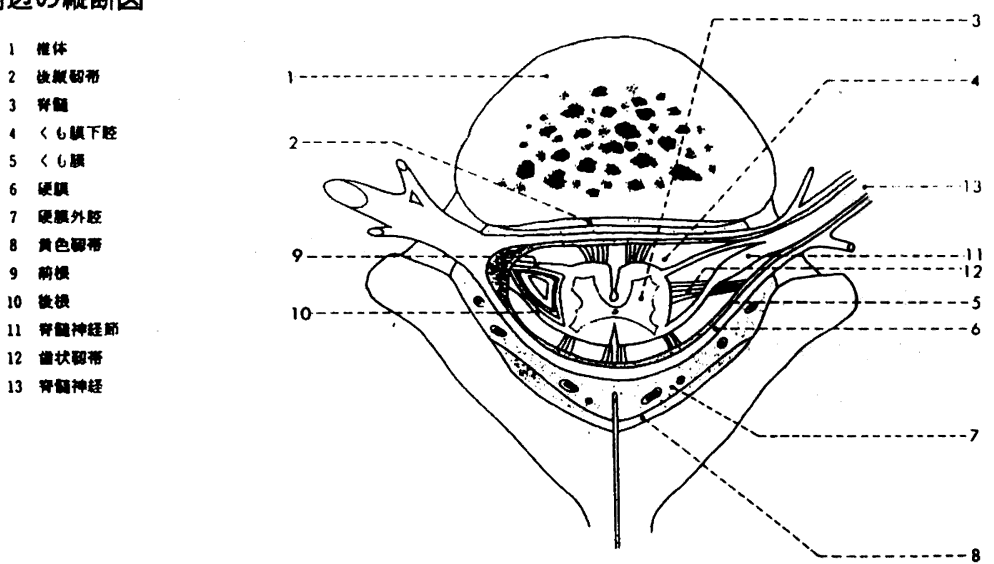


\section{因了屡椎椎间成第の神蛙支配}

\begin{tabular}{|c|c|c|c|c|c|c|}
\hline 1 媵汸 & 4 & l:约筑伎 & 7 & 䄱酘起 & 10 & 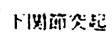 \\
\hline 媵传外国技 & 5 & 下为的技 & 8 & 缋染起 & & \\
\hline 3 媵抾仙技 & 6 & 舦突起 & 9 & 1成丽突起 & & \\
\hline
\end{tabular}

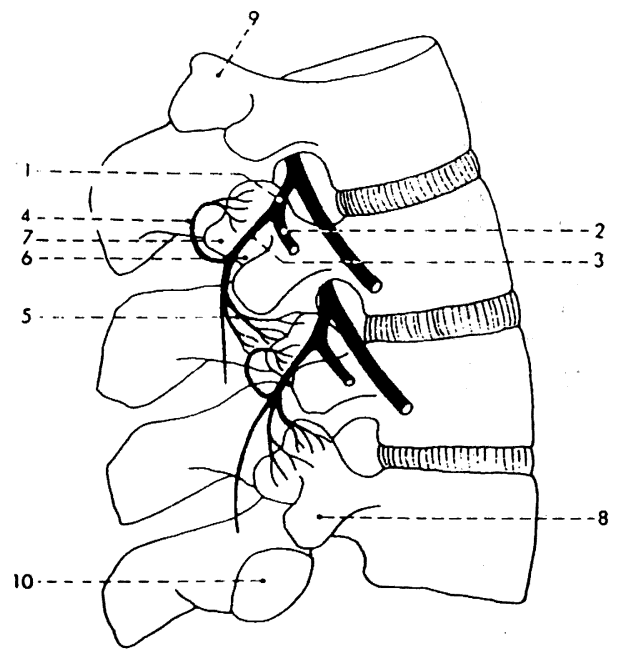

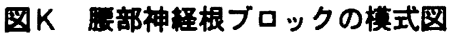

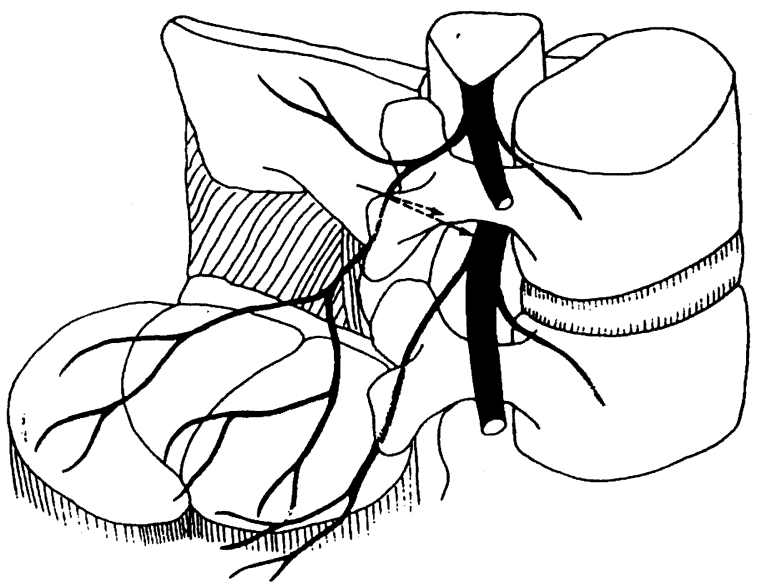

図 2 治痑効果判定基準

\begin{tabular}{|c|c|c|}
\hline & 効 & $\begin{array}{l}\text { 夷肃0，他觉的所見なく，ADL } \\
\text { に支席のないもの }\end{array}$ \\
\hline 有 & 効 & 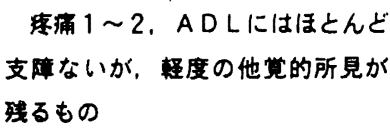 \\
\hline 好 & 快 & 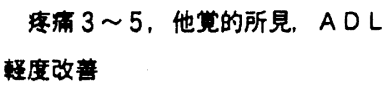 \\
\hline & 変 & 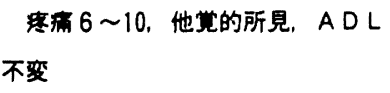 \\
\hline
\end{tabular}


図 3 疾害別治療成績（A群 B 群の比較）

\begin{tabular}{|c|c|c|c|c|}
\hline 名 & 荠効 $(x)$ & 有効 $(x)$ & 柽快( & 不変 $(x)$ \\
\hline 椎周板ヘルニア $\stackrel{\mathrm{A}}{(\mathrm{B})}$ & $\begin{array}{l}32 \\
58\end{array}$ & $\begin{array}{l}27 \\
16\end{array}$ & $\begin{array}{l}13 \\
22\end{array}$ & $\begin{array}{r}28 \\
4\end{array}$ \\
\hline 变形性青椎症 $(\mathbf{A}$ & $\begin{array}{l}54 \\
52\end{array}$ & $\begin{array}{l}24 \\
24\end{array}$ & $\begin{array}{l}16 \\
16\end{array}$ & $\begin{array}{l}6 \\
8\end{array}$ \\
\hline 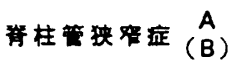 & $\begin{array}{l}20 \\
35\end{array}$ & $\begin{array}{l}28 \\
23\end{array}$ & $\begin{array}{l}28 \\
20\end{array}$ & $\begin{array}{l}24 \\
22\end{array}$ \\
\hline 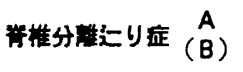 & $\begin{array}{l}23 \\
25\end{array}$ & $\begin{array}{l}45 \\
47\end{array}$ & $\begin{array}{l}2 \\
2\end{array}$ & $\begin{array}{l}30 \\
26\end{array}$ \\
\hline 椎间的笛应 $\stackrel{\text { A }}{\text { (B) }}$ & $\begin{array}{l}52 \\
58\end{array}$ & $\begin{array}{l}10 \\
20\end{array}$ & $\begin{array}{l}34 \\
20\end{array}$ & $\begin{array}{l}4 \\
2\end{array}$ \\
\hline 祖 定 $\stackrel{A}{(B)}$ & $\begin{array}{l}37 \\
35\end{array}$ & $\begin{array}{l}30 \\
30\end{array}$ & $\begin{array}{l}17 \\
17\end{array}$ & $\begin{array}{l}16 \\
18\end{array}$ \\
\hline 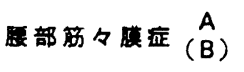 & $\begin{array}{l}84 \\
80\end{array}$ & $\begin{array}{l}16 \\
20\end{array}$ & $\begin{array}{l}0 \\
0\end{array}$ & $\begin{array}{l}0 \\
0\end{array}$ \\
\hline そ $\quad$ 他 $\stackrel{A}{(B)}$ & $\begin{array}{l}30 \\
32\end{array}$ & $\begin{array}{l}16 \\
16\end{array}$ & $\begin{array}{l}12 \\
16\end{array}$ & $\begin{array}{l}42 \\
36\end{array}$ \\
\hline 全 应 例 $\begin{array}{c}A \\
(B)\end{array}$ & $\begin{array}{l}38 \\
43\end{array}$ & $\begin{array}{r}10 \\
9\end{array}$ & $\begin{array}{l}30 \\
29\end{array}$ & $\begin{array}{l}22 \\
19\end{array}$ \\
\hline
\end{tabular}

図M A B A A $\delta \cdot C$ 線雃

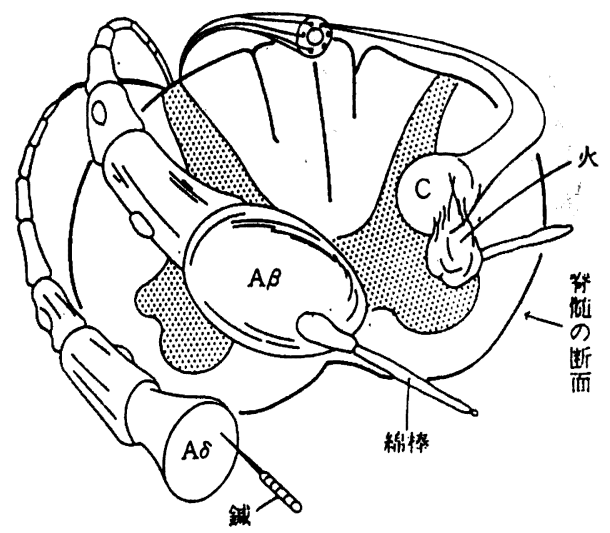

図 4 疾患別治療成縤グラフ

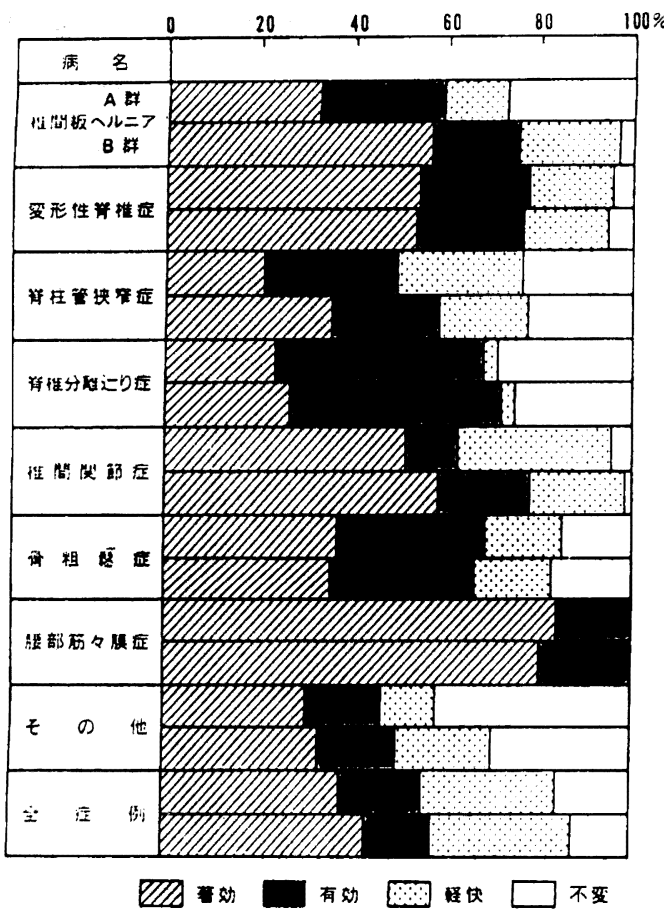

図P 肃みの上行径路

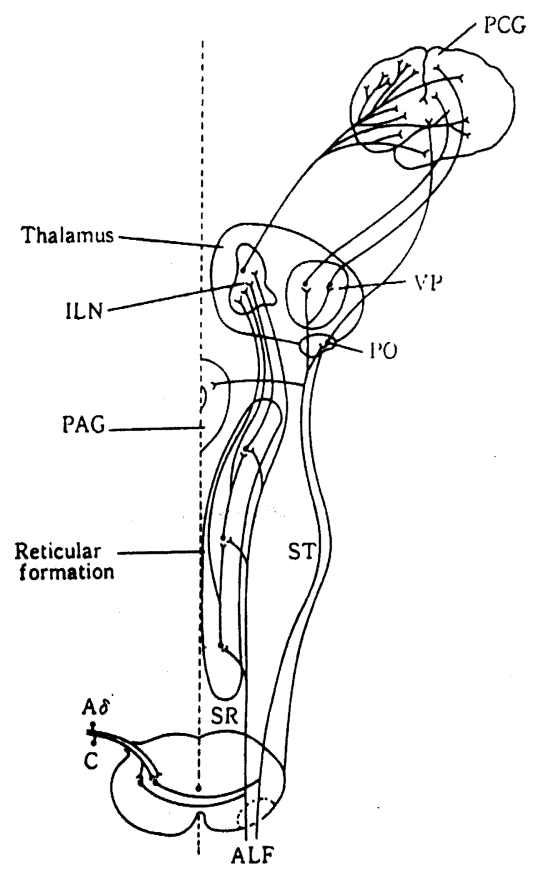


図N ゲートコントロール䂱の简単な説明

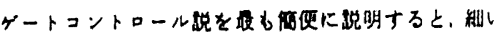

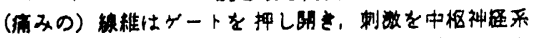

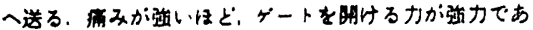

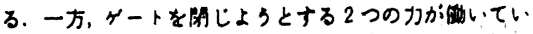

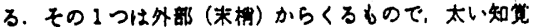

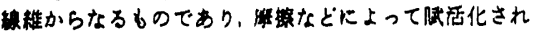

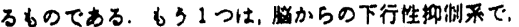
もナィペーションたとえば火東で供を家から䊉い出 ナときは痛みを照しない。

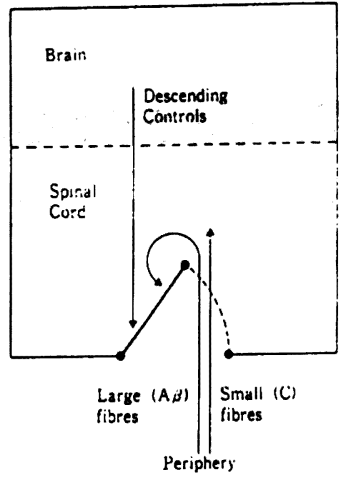

図○下行性抑制系

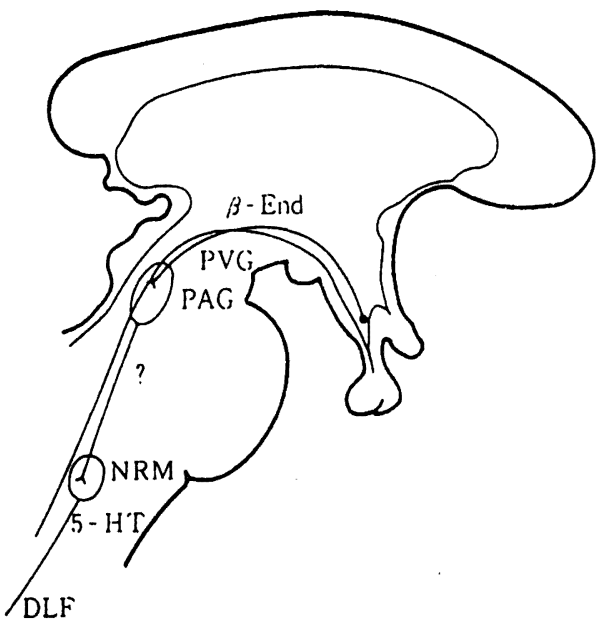

有みの悪循環（図）Qट交惑神経反射

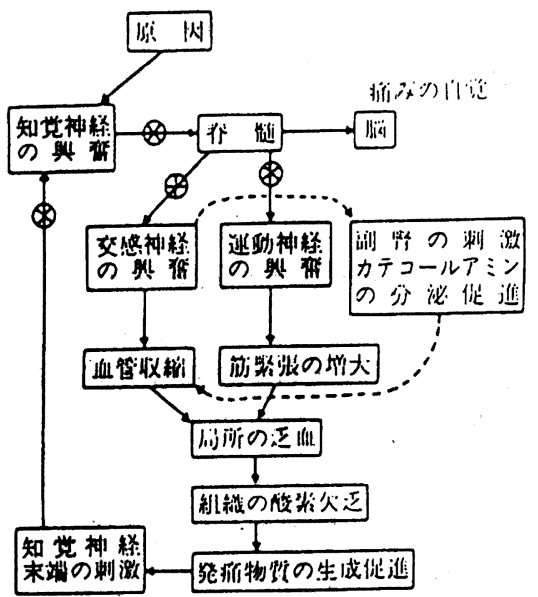

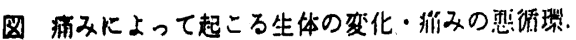
凤の部分に神経ブロックが作用与る。 